Pero tampoco en este segundo nivel de complejidad se resuelve la historia, porque todos los sucesos se determinan mutuamente, suprimiendo así las nociones tradicionales de pasado-presente-futuro.

Resaltemos algunos recursos destructivos, con los que ataca la sintaxis y el género tradicional de la novela, e intenta, al mismo tiempo, renovar estas categorías: la incoherencia del diálogo, el cambio de persona en el relato, el final inusitado en las frases, las repeticiones de palabras, la tipografía caprichosa.

"Tere tete fafa remolino", dice Marrast con un dedo admonitorio. "Bisbis Bisbis", dice Feuille Morte.

"Guti guti", dice mi paredro. "Ptac", dice Calac.

"Poschos toconoto" dice Polanco (p. 63)

Todo esto, como es natural, le parece sumamente estúpido a la señora de Cinamomo ya que, hay que ser francos, parecería que una señora ya no puede venir a pasar un rato de sano esparcimiento en un café. Te lo dije. Lila, vas a ver que terminarán en la cárcel, parecen locos, y se pasan todo el tiempo sacando cosas raras de los bolsillos y diciendo estupideces. (p. 64) -Son tan- dijo Celia-. Mira lo que me escribe Nicole, este párrafo. Están completamente. (p. 141)

mi pobre puta pobre pobrecita puta ( $p, 198)$

Es raro de todos modos/ $S i$, señor, antes no lo miraba nadie/ $Y$ ahora. así.../ Empezó hace unos tres días, y sigue/ (p. 47)

Creo porque es absurdo (p. 198)

Todos estos recursos, además de muchos otros con los cuales el autor arbitra sus historias y cuyo estudio escapa a los límites de esta reseña, demandan la participación dinámica del lector, quien se ve situado fuera de lo real-cotidiano. Para terminar digamos que una vez más vemos en Cortázar un afán de innovar, de experimentar a toda costa, tratando de encontrar nuevas formas expresivas para reemplazar las tradicionales.

Indina University

José María Carranza

of Pennsyluania

Eduardo Mallea. Todo verdor perecerá. Edited by Donald L. Shaw. Edinburgh. Pergamon Press: 1968.

La sección destinada a la América Latina de Pergamon Press se ha lucido con la publicación de esta llamativa edición de Todo verdor perecerá (1941) del argentino Eduardo Mallea, tal como lo hiciera recientemente con Cuentos escogidos de Horacio Quiroga a cargo de Jean Franco y con Spanish American Modernist Poets de Gordon Brotherston.

El trabajo del profesor Shaw aparece distribuido asi: Introducción (estudio monográfico y prólogo a la novelística de Mallea), arreglo cronológico sobre su 
producción, bibliografía auxiliar y un glosario indispensable. Revela Shaw un profundo conocimiento del autor y de su trayectoria de escritor que ayuda a comprender actitudes tan vagamente explicadas hasta hoy tales como: la incomunicabilidad, la soledad espiritual y fisica (esterilidad y desolación en el campo) y la angustia (incertidumbre de todo), nociones todas aplicadas a "hombres herméticos" como Nicanor Cruz, carente de perspectivas de introspección, y "mujeres híspidas" como Agata Cruz para quien la existencia es un dilema desabrido ("o se aguanta uno o se va") que en un plano racional equivalen al compromiso (entrega) o a la renuncia (abstención) frente a la agonía de lo trivialcotidiano. El análisis de Shaw sobre los orígenes de la soledad a la manera en que la define el existencialismo europeo (Europa al borde del caos de la guerra) y sus implicaciones religiosas (la desilusión), la lucha del hombre rioplatense por autoexplicar su destino (Argentina invisible) y la búsqueda de su "yo" aparecen aquí expuestos con hondura y sutileza. Logra también demostrar la prioridad conceptual, en un plano puramente novelístico, de Todo verdor perecerá sobre La noia y L'étranger (Mallea antes que Moravia y Camus). Dilucida la engorrosa querella de Mallea en contra de la "leyenda" de la deshumanización de la novela que le habría de permitir sentar cátedra en torno a la "función extraliteraria" de la novela ("instrumentalidad del género") en contra de la "literatura pura" en candentes polémicas cuyos ecos no acaban de extinguirse ("imágenes para caracterizar y no para embellecer").

Advierte Shaw su tarea de intérprete o mediador frente a una obra "representativa" de Mallea y de lo hispano-americano en la década del 40 al 50 a la par que recuenta el camino recorrido desde Fernández de Lizardi hasta Asturias, Borges y Carpentier. Aparte de cumplir a cabalidad su función de texto escolar, el libro está llamado a convertirse en referencia para todo estudioso de la literatura hispano-americana.

\section{Brown University}

Germán D. Carrillo

Cedomil Gorc. La novela chilena. Los mitos degradados. Santiago: Editorial Universitaria, 'S. A., 1968.

El libro comprende nueve estudios acerca de igual número de novelas consideradas por el autor como obras representativas en la evolución de la narrativa chilena. Desde Don Guillermo (1860), de José V. Lastarria, hasta Coronación (1957), de José Donoso, la novelistica chilena se desarrolla bajo un ritmo generacional cuyas constantes histórico culturales el ensayista presenta según el pensamiento orteguiano, y conforme a fundamentaciones anteriores (Cf. Cedomil Goic, "La novela chilena actual" en Estudios de lengua y literatura como bumanidades; Ed. Universitaria, Santiago, 1960, y "Generación de Dario" en Revista del Pacífico, año IV, No 4, Valparaíso, 1967).

Las obras escogidas representan momentos de cambios significativos dentro del desarrollo del género; son por eso las que permiten ver con mayor rigor el desen- 